\title{
Market Town Household Solid Waste Management: A Case Study of Embu, Kenya
}

\author{
${ }^{1}$ MOCHACHE, M; ${ }^{1}$ YEGON, R; ${ }^{2 *}$ WAKINDIKI, IIC \\ ${ }^{I}$ Department of Land and Water Management, University of Embu, Embu, Kenya \\ ${ }^{2}$ Department of Agriculture and Animal Health, University of South Africa, South Africa \\ *Corresponding AuthorEmail: iwakindiki@gmail.com
}

\begin{abstract}
Household solid waste management directly impacts human health and the environment. Globally, increasing quantities and complexity of household solid waste has become a menace in many market towns. The aim of this study was to establish the status of household solid waste management in the market town of Embu in Kenya. The objectives were to identify the methods used by households to manage solid waste and to establish the factors that influenced the households' choice of solid waste management method. A survey design was deployed and questionnaires were used in data collection. Data analysis was done using the Statistical Package for Social Sciences software. 37\% of the households discarded their solid waste in open places, $32 \%$ burnt and $24 \%$ recycled it. About $8 \%$ households reused the solid waste. Employment, education and access to waste collection services were the major factors influencing household solid waste management strategy. Sustainability of household solid waste management depended on awareness on health and environmental benefits of improved household solid waste management, reduction in household solid waste generation and establishment of a household solid waste management policy for Embu market Town. It was concluded that the current practices for household solid waste management are inadequate. High level of unemployment and low education level hinder proper household solid waste management. Awareness on the health and environmental benefits and policy could improve household waste management in the market town.
\end{abstract}

\section{DOI: https://dx.doi.org/10.4314/jasem.v24i1.15}

Copyright: Copyright (C) 2020 Mochache et al. This is an open access article distributed under the Creative Commons Attribution License (CCL), which permits unrestricted use, distribution, and reproduction in any medium, provided the original work is properly cited.

Dates: Received: 30 November 2019; Revised: 20 December 2019; Accepted: 23 December 2019

Keywords: Recycling, Solid waste, Environmental impact, Sustainability

Solid wastes are unwanted by products of human activities whose management directly impacts human and environmental health (Leton and Omotosho, 2004). Growing quantities of complex solid waste are discarded globally (Vergara and Tchobanoglous, 2012). The problem of household solid waste management is worse in small market towns compared to large metropolis largely due to unavailability of commercial service providers (Adzawla et al., 2019). Thus a serious challenge to authorities managing waste as low income countries rapidly urbanize (Adzawla et al., 2019).

Market towns produce varying quantities of wastes ranging from 5.4 Mega Tonne day ${ }^{-1}$ in Sojitra, India (Pamnani, 2015); 15 Mega Tonne day ${ }^{-1}$ in Gampola, Sri Lanka (Wijerathna et al., 2013); 24 Mega Tonne day $^{-1}$ in Rangpur, Bangladesh, (Rakib et al., 2014); 42 Mega Tonne day ${ }^{-1}$ in Bawku, Ghana (Douti et al., 2017); 59 Mega Tonne day ${ }^{-1}$ in Chiapas, Mexico (Aguilar et al., 2017) and 88 Mega Tonne day ${ }^{-1}$ in Jimma, Ethiopia (Getahun et al., 2012). The quantities produced are determined by the population, urbanization level and lifestyles. These wastes are related to negative environmental impacts such as clogging drains, increased soil erosion, soil and water pollution and negative human health effects.

Effective solid waste management techniques depend on local waste attributes. Waste attributes differ with socioeconomic, climatic and cultural variables as well as institutional capacities (Vergara and Tchobanoglous 2012). Unsustainable solid waste management methods are used in most market towns. For instance, open dumping and burning in Ongata Rongai, Kenya (Gitau, 2018) and Grahamston, South Africa (Godfrey and Oelofse, 2017); open dumping in Manzini Swaziland (Abul 2010) and Borama in Somalia (Abdirahman, 2015) and landfilling in Chandigarh, India (Rana et al., 2015). These unsustainable methods contribute to soil, water and air pollution (Modak et al., 2010). Sustainable waste management strategies include waste reduction, recycling, recovery or treatment (Seadon, 2010). Examples include composting in Juja Kenya (Mwangi et al., 2017).

Most market towns such as Embu are characterized by high population growth rate resulting in increased generation of household solid waste. These include 
Jimma in Ethiopia (Aguilar et al., 2017); Lamu, Kenya (Monyoncho, 2013); Minna, Nigeria (Adeoye et al., 2016); Paradeep, India (Patra and Harichandan, 2015) and Illam, Nepal (Rai et al., 2019) with annual population growth rates ranging from $1.4 \%$ to $3.9 \%$. The aim of the present study was to establish the status of household solid waste management in the market town of Embu. The objectives were to identify the methods used by households to manage the solid waste and the factors influencing the choice of methods.

\section{MATERIALS AND METHODS}

Study Area: The study was done in Embu market town in Kenya. The town is located $120 \mathrm{~km}$ Northeast of Nairobi and on the South Eastern slope of Mount Kenya. The town receives an average annual rainfall of $1120 \mathrm{~mm}$ and average temperatures of $20.2^{\circ} \mathrm{C}$. Population of Embu Town is 41,092 (Kenya National Bureau of Statistics, 2018).

Study Design: The survey design (Ponto, 2015) with stratified random sampling procedure was used to select households and in data analysis. The sample population was calculated using Equation 1 (Yamane, 1967).

$$
n=N / 1+N(e)^{2}
$$

Where; $N=$ Population size, $n=$ Sample size,

$$
e=\text { Error rate }(0.05)
$$

An initial sample size of 400 was determined. However, due to financial constraints, 60 respondents were selected. However, only 40 respondents responded thus giving a response rate of $67 \%$. This return rate was acceptable being above the $60 \%$ return rate recommended by Amin, (2005) for analysis and reporting. Data was collected using a questionnaire comprising open and closed-ended questions.

Data Analysis: Responses in the questionnaire were assigned numerical values. Coding, entering and data analysis was done using IBM SPSS Statistics for Windows (IBM Corp, 2017).

\section{RESULTS AND DISCUSSIONS}

Methods used by households in Embu town to manage the solid waste: Solid waste in Embu town was managed as shown in Figure 1. About 37\% of the households discarded their solid waste in open places, $32 \%$ burnt and $24 \%$ recycled it. About $8 \%$ households reused the solid waste. Burning and open waste disposal were the most preferred household waste management methods (Figure 1). These methods were common in households in areas where waste collection by the County government of Embu was inaccessible or poor. Some of the areas had steep slopes limiting access of waste collection trucks. However, these methods are ineffective posing health and environmental hazards due to air, water and soil pollution (Kalesanwo et al., 2013). For instance, burning wastes results in air pollution from smoke.

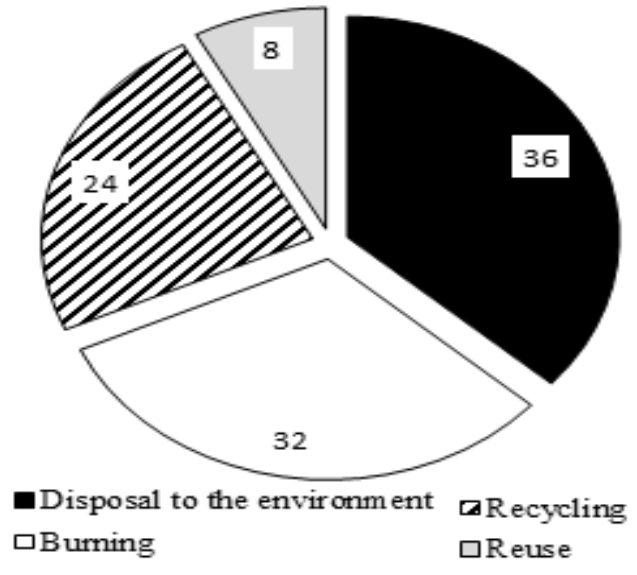

Fig 1. Solid waste management in Embu Town

Market towns have similar challenges of increased waste generation, overflowing dumpsites and pollution from inappropriate waste disposal (Sibanda et al., 2017). Sustainable solid waste management is limited by inadequate funding and the poor attitude of the residents (Kalesanwo et al., 2013). For example, in Gondar, Ethiopia, the municipality provides, waste disposal, transport and disposal services (Gedefaw, 2015). However, the services are not in pace with waste generation resulting in open dumping (Yoada et al., 2014).

In the present study, late collection of waste led to scattering by wind, scavengers or children. In addition, lack of education on the dangers posed by improper solid waste disposal was responsible for respondents choosing ineffective disposal methods. This concurs with Fagariba and Song (2016) who reported ignorance and lack of basic education contributing to improper waste disposal. Similarly, in Ghana, poor education contributed to indiscriminate dumping resulting in flooding during the rainy season as the waste caused blockage of the major storm drains (Adeolu and Adeolu, 2014). Open burning and dumping were attributed to low education in Ibadan, Nigeria (Fredrick and Sentogo, 2018).

Factors influencing the choice of method used by households to manage solid waste: In the current study, education and income characteristics were the main factors influencing the households' choice of solid waste management method. Fifty percent of the 
respondents had attained secondary school and 23\% had primary school education. Twenty seven percent had attained tertiary education. The higher the education level of the respondents, the more insight they had regarding waste management. Income characteristics namely level and consistency determined the household's choice of waste management method. Fifty five percent of the respondents were casuals with low but regular income. Thirty eight percent were self-employed with irregular level and frequency of income. Permanently employed respondents were $7.5 \%$ and had relatively higher regular income. The respondents with a regular income could engage waste collection services either from the Embu County or from private waste collectors. Those on casual employment didn't prioritize waste collection services. Therefore, higher regular income earners disposed their household solid waste appropriately while low irregular earners disposed wastes indiscriminately in the open spaces.

Education administers knowledge, changes attitude as well as promotes skills development to transform societies in resource management, including waste management (Hoang and Kato, 2016). In the present study, education was a key factor in determining people's awareness of waste management with the more learned respondents being more knowledgeable on and employing sustainable waste management options. The findings concur with Zen et al. (2014), who found education an important factor in increasing environmental knowledge through methods such as reuse and recycling. Similarly Boateng et al. (2016) also found households with high education having a deeper understanding and adoption of sustainable waste management and recycling. These findings agree with those of Vassanadumrongdee and Kittipongvises (2017) and Ayuba et al. (2013) who found income a major determinant of choice of waste management options. Besides the level of income, the present study found that regular income encouraged respondents to contract solid waste collection and disposal services.

The present study also found that access to waste collection services determined the household's choice of waste management. Half the respondents had access to waste collection services. Inaccessibility of waste collection services led to poor waste management such as open dumping (Figure 1), open burning, and disposal to the environment. The situation in Embu compares to that of similar market towns such as Bawku in Ghana (Douti et al., 2017) and Tha Khon Yang Municipality in Thailand, where irregularity in waste collection resulted in huge waste piles (Yukalang et al., 2017).
Half the respondents in Embu town did not know any waste collectors. The other half who accessed the waste collection service only obtained the services once per week. This is similar to the situation in Nairobi city (Njoroge and Ndunge 2014) and KwaZulu-Natal, South Africa (Dlamini et al., 2017). Similarly in India, waste collection services are ineffective due to insufficient budgets for municipal authorities responsible for solid waste management (Kumar et al., 2017). A similar case was also reported in Sucre Municipality, Venezuela where solid waste collection is limited by inaccessible hilly areas, leading to overflow of garbage resulting in unsanitary conditions (Ramos and Ortega, 2012).

In the current study, households who could not access the services of waste collectors disposed wastes in different ways (Figure 1). The results of the present study agree with those of other authors. For instance, in Ngomongo Village of Korogocho informal settlement of Nairobi County, households without access to waste collection services dispose their waste by roadside dumping, burning and burying (Ochieng, 2016). A study by Fagariba and Song (2016) also found that in urban Accra, only $61 \%$ of households had access to waste collection services, the remaining 39\% did not have access to waste collection services and dumped their wastes in bushes, holes, streets and gutters. Similarly, in Indian urban areas, waste collection is a challenge resulting in open dumping, which creates environmental and health hazards (Agarwal et al., 2015).

Conclusion: The study concludes that waste is improperly managed in Embu town. For effective waste management in Embu Town, public awareness, waste minimization as well as the implementation of sustainable waste management strategies should be provided. This can effectively be provided by the County government of Embu that is responsible for this function. This provides an opportunity to conduct and implement research findings on sustainable waste management technologies.

\section{REFERENCES}

Abdirahman, M. (2015). Challenges facing Solid Waste Management in Borama Town, Somaliland. A Thesis submitted in partial fulfillment of the requirements for the Degree of Master of Arts in Project Planning and Management, 1-59.

Abul, S. (2010). Environmental and health impact of solid waste disposal at Mangwaneni dumpsite in Manzini: Swaziland. J. Sust. Devt. Africa. 12(7): 64-78 
Adeolu, A; Enesi, D; Adeolu, M. (2014). Assessment of secondary school students' knowledge, attitude and practice towards waste management in Ibadan, Oyo State, Nigeria. J. Res. Environ. Sci. Toxicology. 3(5): 66-73

Adeoye, PA; Sadeeq, MA; Musa, JJ; Adebayo, SE. (2016). Solid waste management in Minna, North Central Nigeria: present practices and future challenges. J. Biod. Enviro. Sci, (1 6): 1-8

Adzawla, W; Tahidu, A; Mustapha, S; Azumah, SB. (2019). Do socioeconomic factors influence households' solid waste disposal systems? Evidence from Ghana. Waste. Mngt. Res. 37 (1): $51-57$

Agarwal, R; Chaudhary, M; Singh, J. (2015). Waste Management Initiatives in India for human wellbeing. Eur. Sci. J. 11(10): 105-127

Aguilar, JAA; Moreno, JCC; Pérez, JAM; RojasValencia, MN. (2017). Municipal solid waste management in a municipality of Chiapas, Mexico. Soc. Sci. 6(5): 133

Amin, E. (2005). Social science research: Conception, methodology and analysis. Makerere University Kampala, Uganda and University of Yaounde, Cameroon: Makerere Printing Press

Ayuba, KA; Manaf, LA; Sabrina, AH; Azmin, SWN. (2013). Current status of municipal solid waste management practise in FCT Abuja. Res. J. Environ. Earth Sci. 5(6): 295-304.

Boateng, S; Amoako, P; Poku, AA; Appiah, DO; Garsonu, EK. (2016). Household Willingness to Pay for solid Waste Disposal Services in Urban Ghana: The Kumasi Metropolis Situation. Ghana J. Geog. 8(2): 1-17

Dlamini, BR; Rampedi, IT; Ifegbesan, AP. (2017). Community Resident's Opinions and Perceptions on the Effectiveness of Waste Management and Recycling Potential in the Umkhanyakude and Zululand District Municipalities in the KwaZuluNatal Province of South Africa. Sustainability. 9(10): 1835

Douti, NB; Abanyie, SK; Ampofo, S. (2017). Solid waste management challenges in urban areas of Ghana: A case study of Bawku Municipality. Earth and Environ. Sci., 8 (4), 494-513
Fagariba, CJ; Song, S. (2016). Assessment of Impediments and Factors Affecting Waste Management: A Case of Accra Metropolis. PrePrints: 1-30

Fredrick, M; Oonyu, JC; Sentongo, J. (2018). Influence of Education on the Solid Waste Management Practices of Communities in Kampala City. J. Environ. Waste Mngt 5(1): 261274

Gedefaw, M. (2015). Assessing the current status of solid waste management of Gondar town, Ethiopia. International Journal of Scientific and Technology Research, 4, 28-36

Getahun, T; Mengistie, E; Haddis, A; Wasie, F; Alemayehu, E; Dadi, D; Van Gerven, T; Van der Bruggen, B. (2012). Municipal solid waste generation in growing urban areas in Africa: current practices and relation to socioeconomic factors in Jimma, Ethiopia. Environ. Mon. Assmnt. 184(10): 6337-6345

Gitau, GC. (2018). Causes and Effects of Poor Solid Waste Management in the Semi-urban Town of Ongata Rongai in Kenya. Int. J. Environ. Health Sci. 1(1)

Godfrey, L; Oelofse, S. (2017). Historical review of waste management and recycling in South Africa. Resources. 6(4): 1-11

Hoang, TTP; Kato, T. (2016). Measuring the effect of environmental education for sustainable development at elementary schools: A case study in Da Nang city, Vietnam. Sustainable Environment Research. 26(6): 274-286

IBM Corp. Released 2017. IBM SPSS Statistics for Windows, Version 25.0. Armonk, NY: IBM Corp

Kalesanwo, OO; Kayode, O; Okufuwa, OA. (2013). Perceived Health Consequences of Indiscriminate Waste Disposal by the Market Women. Med. J. Soc. Sci. 4(14): 553

Kenya National Bureau of Statistics. (2018). Embu County. https://www.knbs.or.ke/download/embucounty/ Accessed 18 February 2019

Kumar, S; Smith, SR; Fowler, G; Velis, C; Kumar, SJ; Arya, S; Kumar, RR; Cheeseman, C. (2017). Challenges and opportunities associated with waste management in India. Royal Soc. Open Sci. $4(3) ; 160764$ 
Leton, T; Omotosho O. (2004). Landfill operations in the Niger delta region of Nigeria. Engin. Geol. 73: 171-177

Modak, P; Jiemian, Y; Hongyuan, Y; Mohanty, CR. (2010). Municipal solid waste management: turning waste into resources. Shanghai manual: a guide for sustainable urban development in the $21^{\text {st }}$ century, $1-36$

Monyoncho, G. (2013). Solid waste management in urban areas Kenya: A case study of Lamu town. A thesis submitted to the Department of Real Estate and Construction Management, University of Nairobi, 1-66

Mwangi, H; Sira, F; Kaluli, W. (2017). Sustainable solid waste management strategies in Juja, Kenya. J. Agric. Sci. Tech. 13 (1): 79-90

Njoroge, B; Kimani, M; Ndunge, D. (2014). Review of municipal solid waste management: A case study of Nairobi, Kenya. Int. J. Engin. Sci. 4(2): $16-20$

Ochieng, G. (2016). Challenges and Possible Interventions for Effective Solid Waste Management in Ngomongo Village of Korogocho Informal Settlement, Nairobi County. A thesis submitted to the Department of Urban and Regional Planning, University of Nairobi, 1-145

Pamnani, A. (2015). Management of Municipal Solid Waste: A case study of small scale Municipality. Int. J. Eng. Sci. Res. Tech. 4 (1): 19-24

Patra, HS; Harichandan, A. (2015). Municipal Solid Waste Management of Paradeep City in OdishaA Review. Int. J. Modrn. Sci. Eng. Tech. 2 (3):19

Rai, KR; Bhattarai, D; Neupanec, S. (2019). Designing solid waste collection strategy in small municipalities of developing countries using choice experiment. J. Urban Manage: 1-10

Rakib, MA; Rahman, MA; Akter, MS; Ali, M; Huda, ME; Bhuiyan, MA. (2014). An emerging city: solid waste generation and recycling approach. Int. J. Sci. Res. Env. Sci. 2(3): 74-84

Ramos, C; Vicentini, A; Ortega, D. (2012). Challenges and opportunities of waste collection in Caracas: Sucre municipality case study. Consilience (7): 115-129
Rana, R; Ganguly, R; Gupta, AK. (2015). An assessment of solid waste management system in Chandigarh city, India. Elec. J. Geotech. Eng. 20: 1547-1572.

Seadon, JK. (2010). Sustainable waste management systems. J. Cleaner Prdn. 18(16-17): 1639-1651

Sibanda, LK; Obange, N; Awuor, FO. (2017). Challenges of Solid Waste Management in Kisumu, Kenya. Paper presented at the Urban Forum, 1-16

Vassanadumrongdee, S; Kittipongvises, S. (2017). Factors influencing source separation intention and willingness to pay for improving waste management in Bangkok, Thailand. Sust. Env. Res. 28: 90-99

Vergara, SE; Tchobanoglous, G (2012). Municipal solid waste and the environment: a global perspective. Annual Rev. Environ. Resources. 37: 277-309

Wijerathna, DMCB; Lee, K; Koide, T; Jinadasa, KBSN; Kawamoto, K; Iijima, S; Herath, GBB; Kalpage, CS; Mangalika, L. (2013). Solid waste generation, characteristics and management within the households in Sri Lankan urban areas. http://www.civil.mrt.ac.lk/conference/ICSBE201 2/SBE-12-241.pdf Accessed 11/3/2019

Yamane, T. (1967). Statistics, An Introductory Analysis, $2^{\text {nd }} E D$., New York: Harper and Row. http://www.sciepub.com/reference/180098.

Accessed 4 April 2019

Yoada, RM; Chirawurah, D; Adongo, PB. (2014). Domestic waste disposal practice and perceptions of private sector waste management in urban Accra. BMC Pub. Health, 14(1), 697

Yukalang, N; Clarke, BD; Ross, KE. (2017). Solid waste management in Thailand: An overview and case study (Tha Khon Yang sub-district). Revs. Environ. Health, 32(3), 223-234

Zen, IS; Noor, ZZ; Yusuf, RO. (2014). The profiles of household solid waste recyclers and non-recyclers in Kuala Lumpur, Malaysia. Habitat Int. 42, 8389 